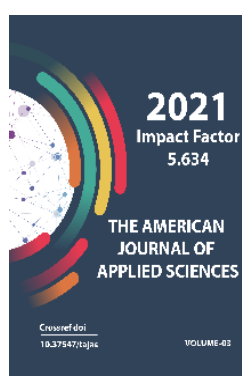

\title{
The Level Of Interregional Cooperation Of The Fergana Valley Provinces
}

\author{
Ravshan Alimovich Sattarov \\ PhD Fellow, Institute Of Forecasting And Macroeconomic Research, Uzbekistan
}

Copyright: Original content from this work may be used under the terms of the creative commons attributes 4.0 licence.

\section{ABSTRACT}

This article discusses about the current level of interregional socio-economic cooperation of Fergana, Namangan and Adijan (Fergana valley) provinces of Uzbekistan.

The purpose of the study is to analyze and give recommendations based on the existing issues on interregional socio-economic cooperation, the level of interdependence, innovation and technologies for business people and government officers of the country.

\section{Scientific novelty of the research:}

1. It is recommended to establish the Organization in Fergana city which can be useful and serve for industry productions sectors of the Fergana, Namangan and Andijan provinces.

2. The establishment of the same above mentioned organizations at the following regions of the country is also recommended: Tashkent, Jizzakh, Samarkand, Kashkadarya and Karakalpakstan regions.

3. For the possibilities of easy access of products' information for local and foreign trade firms, entrepreneurs and consumers in Fergana valley as well as in other mentioned regions is preferable to monitor and gather indicators of products.

\section{KEYWORDS}

Economic regions, trade and services, information base, labor resources, interregional cooperation, scientific and analytical stages, socio-economic issues. 


\section{INTRODUCTION}

Assessing the level of socio-economic interregional cooperation between the regions of the Fergana Valley and the other regions, further strengthening existing ties by identifying systemic problems is very relevant and important in case of Uzbekistan. Because, until this days any research projects has not been conducted in this area, the necessary information base to assess the level of cooperation has not been formed. Official state statistics do not contain information on import and export of goods (services) in each regions in the Fergana Valley. Through a number of available indicators can be used to get a general idea of a certain part of the interaction, without taking into account some errors.

\section{RESEARCH METHODOLOGY}

Scientific abstraction, analysis and synthesis methods were effectively used in this research paper. In particular, I studied Fergana valley provinces socio-economic conditions using the three hundred application questionnaire forms for the purpose of learning the real facing issues among the entrepreneurs and households. The method of presentation directions and separating the regions for socioeconomic cooperation zones of Uzbekistan was mentioned for better design of conclusion and recommendations for the readers.

\section{RESULTS AND FIGURES}

If the formation of the composition of exports and imports is analyzed it can be possible to identify certain imbalances in production of certain products. (Table 1).

In Andijan region, the positive ratio of exports and imports of goods is observed only in foods $(3,822)$. For the other goods the ratio of imported (chemical products are -0.027 , nonferrous metals - 0.048, ferrous metals - 0.072, machinery equipment - 0.129 and services 0.028 ). Almost these trends can be observed in Namangan and Fergana regions.

Objectively, the Fergana valley to satisfy the demands now and in the near future will buy non-ferrous and ferrous metals, chemical and fuel products from abroad and other regions of the country. But for valley, it is desirable to strengthen the process of localization for the production use the own capabilities and potentials in terms of machinery and equipment, foods, services and consumer goods for not importing those products from other parts of the country and abroad.

The indicators show the inflow and outflow of goods (services) and the volume of imports exports of goods by the railways of Fergana valley. (Table 2)

As can be seen from the table products from the valleys and provinces are mainly shipped by railways. (10.5 percent share in the country). The role of railways in the shipment of goods is more than $99.0 \%$. These are mainly products of light automobiles, chemical, gasoline, light and food industries. 
Table 1

Products (services) in the Fergana Valley

formation of the structure of imports and exports

(2020 year, $\mathrm{mln}$. dollars) ${ }^{1}$

\begin{tabular}{|c|c|c|c|c|c|c|}
\hline \multirow{2}{*}{$\begin{array}{c}\text { Products } \\
\text { (services) }\end{array}$} & $\begin{array}{c}\text { Andijon } \\
\text { province }\end{array}$ & $\begin{array}{c}\text { Namangan } \\
\text { province }\end{array}$ & $\begin{array}{c}\text { Fergana } \\
\text { province }\end{array}$ & $\begin{array}{c}\text { Andijon } \\
\text { province }\end{array}$ & $\begin{array}{c}\text { Namangan } \\
\text { province }\end{array}$ & $\begin{array}{c}\text { Fergana } \\
\text { province }\end{array}$ \\
\cline { 2 - 6 } Total & 584,9 & 378,1 & 555,3 & 2211,5 & 493,4 & 907,0 \\
\hline $\begin{array}{c}\text { Including: } \\
\text { cotton fiber }\end{array}$ & 1,1 & 0,4 & 2,7 & - & - & - \\
\hline $\begin{array}{c}\text { Chemical } \\
\text { products }\end{array}$ & 7,0 & 5,4 & 13,3 & 257,6 & 98,0 & 94,0 \\
\hline $\begin{array}{c}\text { Non-ferrous } \\
\text { metals }\end{array}$ & 0,5 & 0,1 & 0,11 & 10,5 & 0,5 & 4,3 \\
\hline Ferrous metals & 11,3 & 10,2 & 2,9 & 156,6 & 43,0 & 36,2 \\
\hline Energy & 0,0 & 0,38 & 6,6 & 14,7 & 12,0 & 193,6 \\
\hline $\begin{array}{c}\text { Machinery and } \\
\text { equipment }\end{array}$ & 192,6 & 8,1 & 1,3 & 149,4 & 179,4 & 291,4 \\
\hline Foods & 51,6 & 104,8 & 207,9 & 13,5 & 72,8 & 119,2 \\
\hline Services & 3,9 & 5,5 & 8,9 & 138,7 & 0,9 & 12,0 \\
\hline Others & 316,8 & 243,0 & 311,7 & 125,9 & 86,8 & 156,2 \\
\hline
\end{tabular}

But these figures are only show some parts of exports from the valley regions and shipments to the other regions. The import-export of goods by railways is not fully regulated in the regions. (transport balance). In general, the lack of balance of products (services) imports \& exports of the official statistics has a negative effect to analyse of socio-economic processes of the regions to determine the level of their overall development, self-sufficiency in basic consumer goods in economic cooperation between regions.

At present taking into account the level of formation of database, the results of local surveys can be used as the main method of assessing inter-regional socio-economic cooperation through a specially designed questionnaire.

The main purpose of the survey conducted by the author was the development of the important economic factors. It consists of identifying the advantages of interregional socio-economic cooperation and effectively using it. The survey also aims to evaluate the existing socio-economic relations between Andijan, Namangan and Fergana regions of the valley population, and ways to expand mutually beneficial cooperation in the future.

\footnotetext{
${ }^{1}$ Calculated based on the data of State Statistics Committee.
} 
Table 2

Goods shipped (transported) by railways and roads in Fergana valley provinces (2019) ${ }^{2}$

\begin{tabular}{|l|c|c|}
\hline \multirow{2}{*}{\multicolumn{1}{c|}{ Regions }} & \multicolumn{2}{|c|}{ Amount of Goods (mln.tn) } \\
\cline { 2 - 3 } & Railway transport & Road transport \\
\hline $\begin{array}{l}\text { Republic of } \\
\text { Uzbekistan }\end{array}$ & 70137,3 & 329,3 \\
\hline $\begin{array}{l}\text { Fergana Valley } \\
\text { provinces: }\end{array}$ & 7390,3 & 46,0 \\
\hline Andijon & 494,5 & 23,1 \\
\hline Namangan & 353,0 & 6,5 \\
\hline Fergana & 6542,8 & 16,4 \\
\hline
\end{tabular}

The survey was conducted in the form of interviews with respondents directly at work places. The questionnaire questions covered four areas. The first is to interview the management groups of the largest industrial enterprises (10) selected in each regions. The second is to establish a dialogue with the management of small and medium-sized businesseses (20), selected in different areas (industry, construction, services) in each regions. Third, direct interviews with households (50) in each provinces. Fourth, evaluate the inter-regional relations with the heads and specialists (10) of each regions (government office workers).
With the managers of large industrial enterprises operating in three regions

I have identified from which regions the raw materials, spare parts and components, tools, machinery and technology is imported. (Table 3). During the survey managers and head of divisions of textile, machinery, food, pharmaceutical, construction materials and chemical industries operating enterprises of the valley actively attended.

\footnotetext{
${ }^{2}$ Calculated based on the data of State Statistics Committee.
} 
Table-3

Fergana Valley regions`share on importing needed large industrial enterprises`raw materials, components, machinery and equipments.

(Percentage of survey results) $^{3}$

\begin{tabular}{|c|c|c|c|c|c|c|c|c|c|}
\hline \multirow{2}{*}{ Regions } & \multicolumn{2}{|c|}{$\begin{array}{c}\text { Andijan province } \\
\text { enterprises }\end{array}$} & \multicolumn{2}{c|}{$\begin{array}{c}\text { Fergana province } \\
\text { Enterprises }\end{array}$} & \multicolumn{2}{c|}{$\begin{array}{c}\text { Namangan province } \\
\text { enterprises }\end{array}$} \\
\cline { 2 - 10 } & $\begin{array}{c}\text { Raw } \\
\text { mater } \\
\text { ials }\end{array}$ & $\begin{array}{c}\text { Compo } \\
\text { nents }\end{array}$ & $\begin{array}{c}\text { Machin } \\
\text { ery and } \\
\text { equipm } \\
\text { ent }\end{array}$ & $\begin{array}{c}\text { Raw } \\
\text { mater } \\
\text { ials }\end{array}$ & $\begin{array}{c}\text { Compo } \\
\text { nents }\end{array}$ & $\begin{array}{c}\text { Machin } \\
\text { ery and } \\
\text { equipm } \\
\text { ent }\end{array}$ & $\begin{array}{c}\text { Raw } \\
\text { mater } \\
\text { ials }\end{array}$ & $\begin{array}{c}\text { Compo } \\
\text { nents }\end{array}$ & $\begin{array}{c}\text { Machin } \\
\text { ery and } \\
\text { equipm } \\
\text { ent }\end{array}$ \\
\hline $\begin{array}{c}\text { Machinery and } \\
\text { equipment }\end{array}$ & 56,0 & 51,0 & 45,0 & 50,0 & 55,0 & 69,0 & 50,0 & 69,0 & 40,0 \\
\hline $\begin{array}{c}\text { From } \\
\text { neighbore } \\
\text { Andijan } \\
\text { province }\end{array}$ & - & - & - & 10,0 & 10,0 & 9,0 & 10,0 & 9,0 & 11,0 \\
\hline $\begin{array}{c}\text { From } \\
\text { neighbore } \\
\text { Fergana } \\
\text { province }\end{array}$ & 11,0 & 7,0 & 2,0 & - & - & - & 5,0 & 13,0 & 10,0 \\
\hline $\begin{array}{c}\text { From } \\
\text { neighbore } \\
\text { Namangan } \\
\text { province }\end{array}$ & 9,0 & 5,0 & 5,5 & 13,0 & 5,0 & 14,0 & - & - & \\
\hline $\begin{array}{c}\text { From the other } \\
\text { province of } \\
\text { Uzbekistan }\end{array}$ & 19,0 & 24,0 & 19,0 & 12,0 & 14,0 & 5,0 & 30,0 & 11,0 & 15,5 \\
\hline From abroad & 5,0 & 6,0 & 11,0 & 15,0 & 11,0 & 14,0 & 5,0 & 10, & 12,0 \\
\hline
\end{tabular}

In general, the raw materials in industrial enterprises (cotton fiber, agricultural raw materials, oil, construction materials, etc.) are obtained from the local regions.

In particular, their share in Andijan is $56.0 \%$ and $50.0 \%$ in Namangan and $50.0 \%$ in Fergana provinces. At the same time, raw materials imported for production from other regions of the country and abroad accounted for $24.0 \%$ in Andijan, 27.0\% in Fergana and $35.0 \%$ in Namangan provinces.

\footnotetext{
${ }^{3}$ Source: Author's calculations based on survey results.
}

The production of components for enterprises in the regions is relatively high, it is higher than $51.0 \%$ in Andijan, $55.0 \%$ in Fergana and $69.0 \%$ in Namangan provinces. However, the share of other regions of the country and foreign countries in the import of necessary machinery and equipment is relatively high. In particular, its share is $30.0 \%$ in Andijan province, $27.0 \%$ in Namangan and $29.0 \%$ in Fergana provinces. According to the results of the analysis, the largest enterprises of the Fergana Valley almost half of the raw materials $25-30 \%$ of components, about $30 \%$ of machinery and 
The American Journal of Applied sciences

(ISSN - 2689-0992)

Published: April 27, 2021 | Pages: 63-69

technology bought from the other regions of the country and abroad. The share of valley regions in importing of components remains low.

For example, the share of Fergana to supply of components to enterprises of Andijan is only $7.0 \%$, and to Namangan $-5.0 \%$. This situation shows the mutual cooperation between the valley regions is not established as required. This has a negative impact on competitiveness and serves as a key factor for high transportation and product costs.
CONCLUSION AND RECOMMENDATION

The results of the assessment by the experts, socio-economic cooperation between the regions of the Fergana Valley is summarized and analyzed by author and some conclusion and recommendations are given.

(Table 4). The level of cooperation in each of the main areas is assessed as following: cooperation level high 8-10 points; cooperation level average 4-7 points; cooperation level is low 0-3 points.

Table 4

Rating system for assessing the level of socio-economic cooperation in Fergana Valley. Survey results, December 2020, percent) ${ }^{4}$

\begin{tabular}{|c|c|c|c|c|c|}
\hline \multirow[t]{2}{*}{ № } & \multirow[b]{2}{*}{ The main areas of cooperation } & \multicolumn{3}{|c|}{ Evaluation criteria } & \multirow{2}{*}{$\begin{array}{l}\text { Final result (points, } \\
\text { rating) }\end{array}$} \\
\hline & & High & Medium & Low & \\
\hline 1. & $\begin{array}{l}\text { Ratio of import and export of products } \\
\text { from the regions }\end{array}$ & - & - & 1 & 1 \\
\hline 2. & $\begin{array}{l}\text { Development of interregional production } \\
\text { infrastructure }\end{array}$ & - & 5 & - & 5 \\
\hline 3. & Interregional industrial cooperation & - & - & 2 & 2 \\
\hline 4. & Mutual investment activity & - & - & - & 0 \\
\hline 5 . & $\begin{array}{l}\text { Cooperation in the field of higher } \\
\text { education }\end{array}$ & - & 4 & - & 4 \\
\hline 6. & Mutual trade & - & 4 & - & 4 \\
\hline 7. & Mutual use of services & - & 4 & - & 4 \\
\hline 8. & Mutual use of workers and professionals & - & - & 3 & 3 \\
\hline 9 . & $\begin{array}{c}\text { Availability of official documents on } \\
\text { cooperation }\end{array}$ & - & - & 0 & 0 \\
\hline
\end{tabular}

According to the conclusion of experts, the formation of production infrastructure and the opportunity of its development is assessed by 5 points and mentioned as a key factor in cooperation, 1st place in the ranking. In the second place, taking into consideration the informal nature of cooperation can be observed in the field of higher education, trade and services. There is also a certain shift in interregional use of the required workers and specialists (third place).

4 Source: Based on the survey results of the expert assessment, systematized by the author. 
Despite the great opportunities the level of industrial cooperation remains low. Basically, it is an informal cooperation in the production of components for automobiles which took fourth place in the ranking. The ratio of imports and exports of interregional products in the valley is negative, and this also belongs to the ratio of exports and imports from/to abroad. (fifth place).

The lowest results of economic cooperation can be assessed by the lack of formal documents of mutual investment activities and interregional cooperation (provinces, cities and districts, formal agreements between entrepreneurs, etc.). (sixth place).

In conclusion, it should be noted that the economic relations between the valley provinces even informally are better comparetivley to other regions of the country. (infrastructure, trade, services, internal migration, cooperation).

However, the lack of documents on the establishment of formal cooperation, mutual aspiration and initiative hinder the expansion of socio-economic ties between the regions.

According to the questionnaire survey the socio-economic cooperation of the Fergana valley remains low, for better and convenient business environment for local and foreign business people, it will be advisable to establish regional cooperation office for above mentioned three provinces in Fergana city.

\section{REFERENCES}

1. Blaug M. Ekonomicheskaya misl v retrospektive. -M, Delo, 1996,-720 s.

2. Savelev Yu.V. Teoriticheskie osnovi sovremennoy mejregionalnoy konkurentsii. Jurnal ekonomicheskoy teorii. 2010. N2. 86-935.

3. Jung (2008) Reviewing Regional Policies under the 'Participatory
4. Government', Journal of Korean Social Trend and Perspective: 81-114 [in

5. Korean] Republic of Korea (2015) South Korea - Summary. [accessed 23

6. November 2015].

7. Granberg A.G. Osnovy regional'noy ekonomiki. - M.:2000. p. 354.

8. Soliev A.S. Regional Economy Tashkent, 2003, $141 \mathrm{p}$.

9. O'zbekiston Respublikasi Prezidenti Shavkat Mirziyoevni Oliy Majlisga murojaati. Toshkent, 24 yanvar 2020 yil.

10. Akhmedov T.M.Strategiya kompleksnogo i ustoychivogo razvitiya regionov

11. Uzbekistana. $\mathrm{V}$ kn.: Modernizatsiya natsional'noy ekonomiki Uzbekistana.

- T.: ANRUz, 2011. - p. 18-21. 